it contained a quantity of grit and gravel. The wall of the bladder at the seat of the rupture was very thin. The left kidney was enlarged and somewhat softened; its pelvis contained pus and a number of calculi, the largest about the size of a hazel nut.

\title{
SUCCESSFUL SERVICE BY A CASTRATED STALLION.
}

By T. G. Heatley, M.R.C.V.S., Woodbridge, Suffolk.

PROBABLY most people if asked whether a horse that had been deprived of both his testicles could procreate his species would unhesitatingly reply in the negative, and yet the answer ought to be in the affirmative, as the following case will show.

On the $24^{\text {th }}$ of June 1896 I castrated a five-year-old Hackney stallion. Three days afterwards the owner, seeing that the horse was apparently in his accustomed form, presented a mare to him, with the result that she was promptly covered. The mare in question was a Hackney, nine years old, which had had a foal when a threeyear-old, but since then had not been covered by any other horse than the above castrated stallion, and by him only on the one occasion, viz., on the 27 th of June 1896 . Between that date and the 5 th of June 1897, when the mare gave birth to a healthy living foal, no horse or colt had access to her. These facts are vouched for by the owner, William Wilson, Esq., Raydon Hall, Orford, Wickham Market.

There is, of course, nothing marvellous in the fact that castration does not instantly deprive an animal of procreative power, for probably in nearly every case living active spermatozoa are left in the vasa differentia and in the vesiculæe seminales. What is really the the most wonderful fact in connection with this case is that the animal still had the sexual instinct as late as the third day after castration, and was so little inconvenienced by the after-effects of the operation that he was not deterred from the act of copulation.

\section{GURIOUS LESIONS OF NAVICULAR BONES.}

THE somewhat remarkable navicular bones reproduced in the left-hand bottom figure of Plate II I. (facing p. 295) were forwarded by Vet.-Captain Pease, Principal of the Lahore Veterinary College, with the history that they were taken from an old East Indian pony which had suffered from an incurable lameness of both fore feet, simulating navicular disease. In each case the abnormality affects the lower edge of the bone, behind the surface by which it articulates with the os pedis. In the one bone (the uppermost in the figure) this edge shows two rough shallow pits, as if two pieces of bone had been broken off. In an exactly similar position in the other bone this edge carries two little pieces of bone which also look as if they had been broken off: they are now firmly joined to the edge of the navicular by bony union. The appearance of the parts suggests that under strain small pieces of bone giving attachment to the interosseous ligament of the coffin joint had been torn off. 